\title{
Perceptions and adaptations to climate change in Southern Mali
}

\author{
Tiémoko SOUMAORO \\ PhD student at the UFR of Economics and Management, Gaston Berger University (UGB) of \\ Saint-Louis, Senegal.
}

tiemoko.soumaoro39@yahoo.com

\begin{abstract}
This study aims to determine the impact of climate change on market garden production in the extreme south of Mali through the perception and adaptation of market gardeners to climatic phenomena. The study used two models, namely the probit selection and Heckman results models and multinomial logistic regression, based on data collected from producers. A total of 194 producers were surveyed. The results of Heckman's probit model indicate that experience in agriculture and the educational level of the producers are the two main determinants of producers' perception and simultaneous adaptation to climate change. Among these variables agricultural experience is both positively and negatively correlated with perception.
\end{abstract}

Keywords: Adaptation, climate change, southern Mali, Heckman probit, vegetable production

\section{INTRODUCTION}

Climate change and its impacts have now become one of the greatest challenges for humanity, its environment and its economies (IPCC, 2013). At the global level, climate change is reflected in the rise in the average temperature of the planet, the melting of glaciers, the rise in sea level and the increase in the frequency of extreme events, the disappearance of species of animal origin, changes in rainfall patterns, etc. The average temperature in the world will increase by $1.8^{\circ} \mathrm{C}$ to $4^{\circ} \mathrm{C}$, and in the worst case $6.4^{\circ} \mathrm{C}$ by the end of this century (IPCC, 2007). Developing countries are particularly vulnerable to the adverse effects of climate change because their economies are mainly based on highly climate-sensitive natural resources and their limited adaptive capacities. According to the $\mathrm{FAO}^{1}$, climate change threatens to cause significant declines in agricultural and livestock production systems (up to an estimated 50\% reduction in rainfed cereal yields by 2050) as well as continued degradation of ecosystems already under excessive stress.

\footnotetext{
${ }^{1}$ http://www.fao.org/agriculture/ippm/activities/climate-change-adaptation/fr/
} 
In Africa, climate change and land degradation threaten the survival and livelihoods of millions of people (Sultan, 2011). Soil fertility is declining in many parts of the continent. The 5th Assessment Report of the Intergovernmental Panel on Climate Change (IPCC, 2014) is alarming and quite revealing of the level of vulnerability of the African continent. It is estimated that 75-250 million people in Africa will face significant water stress by 2020 and 350-600 million by 2050 due to climate change; that agricultural production in Africa will be severely compromised due to loss of land, shorter growing seasons and increased uncertainty about the nature and timing of planting, it also predicts a possible 50\% reduction in rainfed crop yields by 2020 in some North African countries and a potential $90 \%$ reduction in net crop income by 2100 in South Africa.

Mali is considered one of the most vulnerable countries in the world to climate change due to its geographical location (semi-arid tropical), but also due to its economic dependence on agriculture and the recurrence of natural risks (droughts and floods). Thus, droughts and floods account for $80 \%$ of the loss of life and $70 \%$ of the economic losses related to natural hazards in sub-Saharan Africa (Bhavnani et al. 2008). Between 1951-1970, there was a 20\% drop in comparison with the reference period 1971-2000 leading to a displacement of isohyets by $200 \mathrm{~km}$ towards the South (MEDD, 2018). According to the same source, the $1200 \mathrm{~mm}$ isohyets no longer exist on the map of Mali. This shows how irregular the rainfall regime in Mali is.

Faced with these challenges, in order to increase food and nutrition security, farming communities in Mali's regions have developed adaptation strategies that improve the productivity, efficiency, profitability and equity of their agricultural production and marketing systems (UNDP, 2014).

In addition, agriculture provides employment for more than $70 \%$ of the rural population and is the main source of income (World Bank, 2014). With the galloping urbanisation of Malian cities, there has been a strong increase in the demand for market garden produce, resulting from the change in consumer habits. In this case, market gardening appears to be a sector in the making.

Moreover, most market gardening systems are not capital intensive at the outset. Moreover, market gardening is an income generating activity for the farmers. Not only does it help to improve their socio-economic living conditions and address the recurrent problem of food insecurity.

However, current and future climatic disturbances risk compromising the development of market gardening where agro-climatic conditions are increasingly difficult (Rushigira, 2017).

Changing rainfall patterns and rising temperatures are currently hampering market gardening activity due to the low availability of irrigation water. This situation is leading to a drop in market garden production yields.

Several researchers have paid particular attention to climate change and agriculture in general, and few studies have focused research specifically on climate change and market gardening. The present study aims to determine the impact of climate change on vegetable production in the extreme south of Mali through the perception and adaptation of market gardeners to climate change.

Thus, the main objective of this study is to understand the long-term perceptions and 
analyse the adaptation measures undertaken by market garden producers in the extreme south of Mali. More specifically, it aims to analyse the factors that influence farmers' perceptions and their adaptation to climate change and variability in the extreme south of Mali.

\section{Materials and Methods}

\subsection{Choice of study areas}

Located in the extreme south of Mali, the Sikasso region is bordered to the north-west by the Koulikoro region, to the north-east by the Ségou region, to the east by Burkina Faso, to the south by Côte d'Ivoire and to the west by Guinea. The region of Sikasso is divided into seven circles which are: Bougouni, Kadiolo, Kolondiéba, Koutiala, Sikasso, Yanfolila and Yorosso.

The relief is made up of hills and mountains in the south, and valleys and plains in the center and north. The Kénédougou massif peaks at $800 \mathrm{~m}$. In addition, the Sikasso region is a reservoir of the Upper Niger watershed. It is crossed by numerous rivers, tributaries of the Niger River: the Sankarani in the north which collects water and discharges it into the Niger upstream of Bamako and the Bani in the south which joins the Niger at Mopti after collecting the waters of the Baoulé, Bagoé and Banifing.

The climate is of the tropical Sudanian type, subdivided into two climatic zones: the humid Sudanian zone and the Guinean zone. This region remains the most humid in Mali and the wettest ( 700 to $1,200 \mathrm{~mm} /$ year). The average annual temperature is $27^{\circ} \mathrm{C}$. It is also characterised by its predominance in agricultural production. The choice of this zone is based on the criteria of the climatic regime and its high vegetable production. Like the other regions of Mali, the circles surveyed are among the most vulnerable zones, like all the circles in the southern region, to the manifestations of climatic phenomena.

\subsection{Sampling}

The multi-stage random sampling technique was used for this study. First, three agricultural zones (Bougouni, Koutiala and Sikasso) in the far south were selected. In each agricultural zone, two communes were selected at random. In each of the communes, villages were sampled in proportion to the size of the village. Thus, five Communes were sampled in three Circles in the region. Two reasons prevailed in the choice of the communes and villages selected: the high concentration of market garden produce and the accessibility of the area.

Producers were selected from a list of households that are market gardening in the villages and this list was obtained from the World Vegetable Center (WCA) of the $<<$ Horticulture Scaling Project 2019 $>>$ programme. A total of 224 producers were randomly selected. However, the study revealed only 194 valid responses and was used for data analysis. On the other hand, 30 people from the Commune of Sokourani in the Koutiala circle could not answer our survey, most of them had been absent at the time of our visit to the Commune (5 men and 10 women), others had moved ( 2 men and 5 women) and the others were either away for treatment or other reasons. Table 1 shows the distribution of the sample in the surveyed areas. Table 1 shows the distribution of the sample in the surveyed areas. 
Table 1. Composition of the study sample

\begin{tabular}{|c|c|c|c|c|c|}
\hline $\begin{array}{c}\text { Agricultural } \\
\text { Area }\end{array}$ & Commune & Village & $\begin{array}{l}\text { Number of } \\
\text { households }\end{array}$ & Sample size & $\begin{array}{c}\text { Response } \\
\text { rate } \\
(\%)\end{array}$ \\
\hline \multirow{4}{*}{ Bougouni } & \multirow{2}{*}{ Koumantou } & Choubougou & 24 & 24 & 100 \\
\hline & & Ména & 24 & 24 & 100 \\
\hline & Sanso & Finkoua & 24 & 24 & 100 \\
\hline & Zantiébougou & Koury & 24 & 24 & 100 \\
\hline Koutiala & Zankaso & Sokourani & 80 & 50 & 62 \\
\hline \multirow{2}{*}{ Sikasso } & \multirow{2}{*}{ Niéna } & N'golotiorla & 24 & 24 & 100 \\
\hline & & Tiécourala & 24 & 24 & 100 \\
\hline \multicolumn{3}{|c|}{ Total } & 224 & 194 & 86,6 \\
\hline
\end{tabular}

Source: Field survey, August-October 2019

\subsection{Collection method}

The data collection took place in 2 stages: the pre-collection or concept clarification phase and the actual collection. The questionnaire and the interview guide were used as a guide for the collection of information. The pre-collection phase: this is a transitional phase and allows for the detection of errors in the questionnaire. Then, the choice of producers was made randomly from an exhaustive list of all the beneficiaries of the World Vegetable Center (WCA) $<<$ Horticulture Scaling Project 2019 $>>$ project.

The focus group discussions were composed of resource persons and experienced producers with at least 15 years of experience in animal or crop production. On average, in each village 2 focus groups of 10 to 15 people (men and women) were set up separately in order to identify the perceptions and adaptation measures of each group. In addition, individual interviews were conducted with beneficiaries to understand the perceptions of other beneficiaries at the local level. A total of 194 market gardeners were surveyed. Questions focused on household and farm characteristics, infrastructure and institutional factors likely to influence the perceptions and use of adaptation methods by producers.

\subsection{Theoretical framework}

Perception is a process of receiving information and stimuli from our environment and converting them into psychological reactivity. The perception of climate change, as an extremely difficult idea for farmers, has its limits because the individual's perception differs from past and present situations (Van den Ban et al, 2000).

In the literature two models are commonly used to analyse the determinants of producers' choice or decision to make adjustments or changes, such as adopting strategies or technologies. These are Logit and Probit (Maddison, 2007; Hassan and Nhemachena, 2008; Gbetibouo, 2009). Depending on the nature of the dependent variable (dichotomous dummy or with more than two modalities) multinomial models are also used. These models are presented in the general form:

Where:

$$
A_{i}=f\left(Z_{i}\right)
$$


$A_{i}$ and $Z_{i}$ respectively represent the producer's adaptation decision $i$ and a set of demographic and socio-economic characteristics of the same producer $i$.

Taking into account the link that exists between perception and adaptation, the simplest way is to integrate the producer's perception. $i$ in the model (1) and to express in this form:

$$
A_{i}=f\left(Z_{i}, P_{i}\right)
$$

With this new notation, perception appears as an endogenous variable (a function of a certain number of characteristics specific to the individual). In this case, equation (2) presents an endogeneity bias. If we split the two equations in order to overcome this endogeneity problem, we can see that the two equations have a bias of endogeneity. Let the equation be:

$$
\begin{gathered}
A_{i}=f\left(Z_{i}\right) \\
P_{i}=f\left(Y_{i}\right)
\end{gathered}
$$

Where:

$Y_{i}$ represents a set of vectors of the producer's own characteristics $i$. Although this new formulation limits estimation bias, it does not take into account the relationship between perception and adaptation. According to Maddison (2007) and Gbetibouo (2009), perception is a prerequisite for adaptation. In other words, one must perceive before adapting. The problem of endogeneity no longer arises, but rather of selection: adaptation if perception. To better capture the relationship between adaptation and perception, Maddison (2007), Deressa et al (2008) and Gbetibouo (2009) propose the use of a Heckman probit selection model.

The final model is then written:

$$
\begin{gathered}
A_{i}=f\left(Z_{i}\right) \\
\text { If and only if } \\
P_{i}=f\left(Y_{i}\right)>0
\end{gathered}
$$

This assumption is only valid if the selection equation (the perception equation) includes at least one variable that is not included in the adaptation equation.

The reduced form is written:

$$
\begin{gathered}
a_{i}=\alpha_{0}+\sum_{j} \alpha_{j} Z_{i j}+u_{i} \\
\text { If and only if } \\
p_{i}=\beta_{0}+\sum_{j} \beta_{j}, Y_{i j^{\prime}}+v>0
\end{gathered}
$$

In this model, $a_{i}$ is the producer's decision to adapt ( $1=$ adapts and 0 otherwise) $i$ and $p_{i}$ its perception defined as a binary variable ( $1=$ perceives and 0 otherwise); $\alpha$ and $\beta$ are parameters to be estimated, $u$ and $v$ are terms of error.

In Ethiopia, Deressa et al (2008), applied multinomial logistic regression (MNL) for the analysis of determinants of farmers' adaptation options and perceptions of climate change in the Nile Basin of Ethiopia. The results of their estimates indicate that the level of education, gender, age and income of the head of household, access to extension services and agricultural credit, 
climate information, agro-ecological zone and as well as temperature all influence farmers' choices.

In Mali, Sanogo et al (2017), collected data on 400 small farmers to elucidate farmers' perceptions of climate change in southern Mali and the potential consequences for delivery using the multinomial logit model. Their results revealed an increase in the frequency of high winds, dust, drought, high temperatures and the number of hot days as the main indicators related to climate change.

\subsection{Model specification}

\section{Functional form}

Two types of analytical models are used in this study. The first model examines producers' perceptions and adaptations to climate change in the extreme south of Mali, while the second model analyses what determines the method chosen by producers to adapt to climate change.

\section{Analysis of farmers' perception and adaptation to climate change}

Adaptation to climate change is a two-step estimation process: first, perceiving the change and, second, deciding whether or not to adapt by adopting a particular measure. At this level, a sample selection problem then arises, as only those who perceive climate change will adjust, whereas we need to make an inference about adaptation on the agricultural population in general, which involves the use of Heckman's probit model of sample selection (Maddison, 2006).

The probit model with sample selection (Van de Ven and Van Pragg, 1981) assumes that there is an underlying relationship.

$y_{j}^{*}=X_{j} \beta+u_{1 j}$ Latent équation

In such a way that only the binary result is observed.

$y_{j}^{\text {Probit }}=\left(y_{j}^{*}\right)>0 \quad$ Equation de probit

The dependent variable, however, is not always observed. Rather, the dependent variable is observed for observation $\mathrm{j}$ if:

$y_{j}^{\text {select }}=\left(Z_{j} \gamma+u_{2 j}>0\right)$ Selection equation

$$
\begin{gathered}
\mu_{1} \sim N(0,1) \\
\mu_{2} \sim N(0,1) \\
\operatorname{Corr}\left(\mu_{1}, \mu_{2}\right)=\rho
\end{gathered}
$$

When $\rho \neq 0$ The standard probit techniques applied to the first equation give biased results. Heckprobit provides consistent and asymptotically efficient estimates for all parameters in these models.

For the model to be properly identified, the selection equation must include at least one variable that is not included in the probit equation. Otherwise, the model is only identified by its functional form and the coefficients have no structural interpretation. 


\section{Empirical model}

Based on the results obtained by Maddison (2007) and Deressa et al (2008) and taking into account the characteristics of Mali's climate, the functional form adopted for the present study is as follows:

- the linear specification of Heckman's selection model

$$
P_{i}=\alpha_{0}+\alpha_{1} * \operatorname{Exp}_{\text {Prod }_{i}}+\alpha_{2} * \operatorname{Sex}_{\text {Prod }_{i}}+\alpha_{3} * \operatorname{Memb}_{O_{i}}+\alpha_{4} * \operatorname{Niv}_{-} E_{d u C_{P o d_{i}}}
$$

Where:

Exp_Prod: Producer's experience; Sex_Prod: Gender of producer; Memb_OP: Member of a farmers' organisation; Level_Educ: Level of education of the producer.

- the linear specification of Heckman's probit result model

$A_{i}=\beta_{0}+\beta_{1} * \operatorname{Exp}_{\text {Prod }_{i}}+\beta_{2} * \operatorname{Sex}_{\text {Prod }_{i}}+\beta_{3} * \operatorname{Memb}_{O P_{i}}+\beta_{4} * \operatorname{Age}_{\text {Prod }_{i}}+$ $\beta_{5 *}$ Tail $_{\text {men }}+\beta_{6} *$ Acc $_{\text {crd }}+\beta_{7} *$ Acc $_{\text {Vulg }}+\beta_{8 *}$ Acc Info $_{\text {climat- }}+\beta_{9}$ Mod_Ter

Where:

Age_Prod: Age of producer; Tail_men: Household size; Acc_crd: Access to credit; Acc_Vulg: Access to extension service; Acc_Info_climate: Access to climate information; Mod_Ter: Mode of access to land.

Table 2. List of independent variables and expected signs

\begin{tabular}{lcc}
\hline & \multicolumn{2}{c}{ Expected signs } \\
\cline { 2 - 3 } & Adaptation model & $\begin{array}{c}\text { Perception } \\
\text { model }\end{array}$ \\
\hline Age of the producer & + & + \\
Size of household & + & + \\
Experience & - & - \\
Gender of producer $(1 / 0)$ & + & - \\
Access to credit $(1 / 0)$ & + & + \\
Access to extension $(1 / 0)$ & + & $+/-$ \\
Mode of access to land & $+/-$ & + \\
Access to climate info $(1 / 0)$ & $+/-$ & - \\
Level of education $(1 / 0)$ & + &
\end{tabular}

Source: Author according to theoretical and empirical literature review

\subsection{Definition of variables}

\section{- Dependent variable}

To assess the factors that influence farmers' perceptions of climate change and variability in the extreme south of Mali, the Heckman Probit breeding model was used. Farmers' perception as a dependent variable is a dummy variable taking the value 1 if the farmer perceives climate change and 0 otherwise.

- The independent variables for the selection equation 
For the selection equation, we make the following hypothesis: education, age of the producer is a proxy for experience, gender of the producer, membership of a farmer organisation influence producers' awareness of climate change.

\section{Explanatory variables for the results equation}

Variables assumed to influence adaptation include the age of the producer, household size, number of years of farming experience, gender of the producer, access to credit, access to extension services, access to information on climate change, membership of farmer organisations and mode of access to land.

\section{Results and discussion}

\subsection{Descriptive and econometric analysis of farmers' perceptions and measures to adapt to climate change}

\subsubsection{Farmers' perception of climate change}

This section presents descriptive analyses of the variables that are assumed to influence producers' perceptions of climate change in the study area.

A number of questions were asked to better understand what farmers think about longterm changes in climatic variables (rainfall and temperature). In all the sampled Communes, it was found that $85.56 \%$ of respondents said they had observed and noticed long-term changes in climatic phenomena over the last 20 years, compared to $14.44 \%$.

\section{Figure 1: Producers' perceptions of climate change}

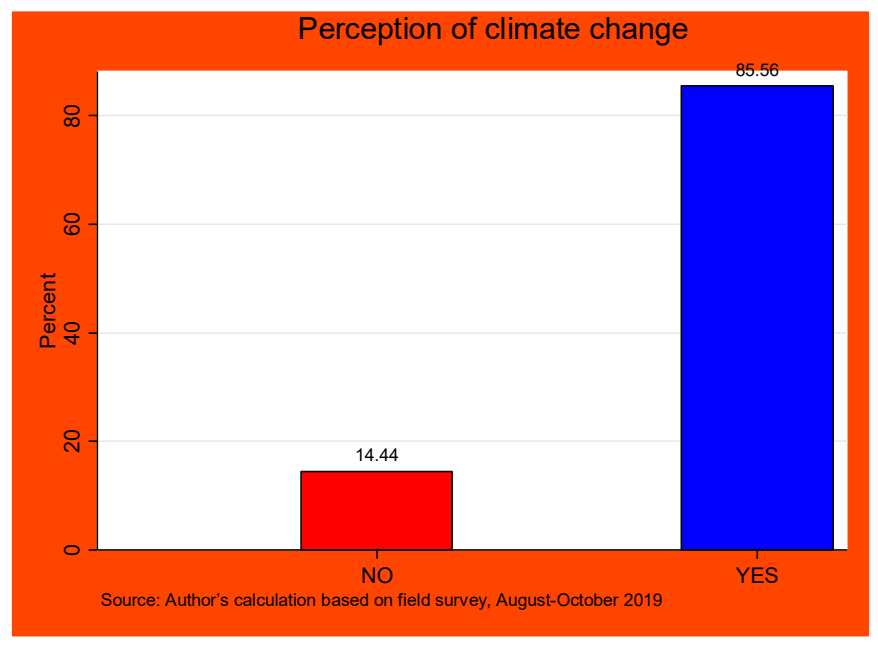

Table 2 presents the results of the descriptive analysis of independent variables expected to influence farmers' perceptions of climate change.

The distribution of respondents according to the number of years of experience shows that the average experience in agricultural production is about 13 years. More than half of the farmers in the study sample (57\%) declared that they belonged to at least one formal farmers' organisation. Indeed, $66 \%$ of the farmers surveyed are women and $37 \%$ are men. The majority of the sample had no level of education $(53.48 \%)$ and only $3.74 \%$ had reached secondary school. 
Tableau 2: Description des variables du modèle de sélection du probit de Heckman

\begin{tabular}{lcc}
\hline Qualitative variables & Absolute frequency & Relative frequency (\%) \\
\hline Gender of producer & - & - \\
Women & 128 & 66 \\
Man & 66 & 34 \\
Belonging to a PO & 111 & 57 \\
Level of education & 90 & 46,40 \\
\hline Qualitative variables & Averages & Standard Deviation \\
\hline Experience & 12.66 & 7.97 \\
\hline
\end{tabular}

Source: Author's calculation based on field survey, August-October 2019

Table 3 below shows the percentage of farmers who have observed long-term changes in different climatic phenomena. About 55\% observed an increase in temperature levels while $86.63 \%$ observed less rainfall. The results also indicate that about $87.17 \%$ of market gardeners admitted to having noticed a change in the rainfall pattern. They reported that rainfall starts late and ends early and when it does, the dry season follows and lasts for a long period (according to $87.70 \%$ of the market gardeners). This is followed by an increase in the frequency of droughts (noted by $77.01 \%$ of market gardeners). Only $37 \%$ of the market gardeners observed an increase in heavy and long periods of rainfall, while about $52 \%$ observed a decrease. In addition, they denied that the decrease in yields is linked to the degradation of agricultural land (noted by $78.61 \%$ of market gardeners). This information was collected from producers during the focus group discussions that heavy rainfall that lasted for a short period of time has increased.

Table 3: Long-term perception of different climatic phenomena in (\%).

\begin{tabular}{lccc}
\hline & \multicolumn{3}{c}{ Direction of change (\%) } \\
\cline { 2 - 4 } Climatic phenomena & Diminished & Increased & Unchanged \\
\hline Early rains & 18.72 & 60.43 & 20.86 \\
Precipitation starts late and ends early & 6.42 & 87.17 & 6.42 \\
Delay in the start of wintering & 6.42 & 85.56 & 8.02 \\
Long dry season period & 5.88 & 87.70 & 6.42 \\
Strong and long period of precipitation & 52 & 37 & 11 \\
Less rainfall & 5.35 & 86.63 & 8.02 \\
High temperature & 3.21 & 54.55 & 42.25 \\
Floods & 33.16 & 51.34 & 15.51 \\
Drought & 9.63 & 77.01 & 13.37 \\
Land degradation/Decrease in fertility & 8.02 & 78.61 & 13.37 \\
Drainage of streams (or strong wind) & 7.49 & 80.21 & 12.30 \\
Overflowing streams/rivers (or Tourbillon)) & 60.43 & 25.13 & 14.44 \\
\hline Source: & Author's calculation based 0 n fin
\end{tabular}

Source: Author's calculations based on field survey data, August-October 2019.

\subsection{Adaptation measures perceived by producers}

Increasing cultivated land, soil and water conservation and the use of drought-resistant crops remain the main adaptation methods perceived by producers $(97.33 \%$; $93.05 \%$ and $84.49 \%$ respectively). These options could be a better option for coping with the adverse effects of climate change and variability. About $53 \%$ of producers said they rely only on their own weather forecasts to discern the right time for the first rainfall so that they sow early or wait for rain and then plant to avoid the associated effects of delayed rainfall. This is the information gathered during the group interviews. Furthermore $31.55 \%$ of the farmers felt that another option is to combine trees and crops (agroforestry) in the same plot for different purposes is 
also a good alternative to consider. In this way it is possible to reduce the risk of huge production losses due to extreme weather phenomena. In addition, $31.02 \%$ of the farmers surveyed stated that they perceived crop rotation as one of the adaptation measures. The adaptation measures least perceived by producers are mulching, working off-farm and use of wetlands and river valleys $(7.49 \%$ and $2.13 \%$ of producers respectively).

Table 4: Adaptation option adopted by producers

\begin{tabular}{lcc}
\hline Perceived adaptation option by producer & Number of producers & $\begin{array}{c}\text { \% per } \\
\text { producer }\end{array}$ \\
\hline Off-farm employment & 4 & 2.13 \\
Increase irrigation & 9 & 4.81 \\
Mulching & 14 & 7.49 \\
Use of wetlands/river valleys & 4 & 2.13 \\
Drought-resistant crop & 158 & 84.49 \\
Different crop varieties & 29 & 15.51 \\
Use of a traditional crop variety & 29 & 15.51 \\
Increase in cultivated land & 182 & 97.33 \\
Crop rotation & 59 & 31.02 \\
Intercropping & 26 & 13.90 \\
Agroforestry use (Tree planting) & 58 & 31.55 \\
Water and soil conservation & 174 & 93.05 \\
Early and late planting & 98 & 52.41 \\
\hline Num
\end{tabular}

\section{Number of observations $=194$}

\subsection{Predicting climate change and variability}

In this section, we present a number of endogenous techniques mainly used by producers to predict the onset of the rainy season and the climatic risks (floods and droughts) that may occur during the rainy season without referring to the information provided by meteorological services. For this question, market gardeners were allowed to answer more than one technical question based on their different predictions. Table 5 below shows a list of local techniques used by farmers to predict the onset of the rainy season and the extension of the rainy season as a result of flooding. Overall, the results show that opinions are very mixed, with almost half of the producers stating that they know the exact time of the rainy season when the birds are moving in numbers. Similarly, $19.79 \%$ of the producers in the study sample refer to bird songs to predict the early onset of the rainy season, while $10.16 \%$ of the producers are more interested in rivers. In addition, during the focus group discussions, the producers of the Circle of Sikasso explained that when they see a long line of insects lining up to ensure that the rainy season is about to begin.

Table 5: Prediction of the early onset of the rainy season

\begin{tabular}{lcccc}
\hline Prediction techniques & BOUGOUNI & KOUTIALA & SIKASSO & TOTAL \\
\hline Heavy and overcast sky & 4.12 & 0.00 & 4.00 & $\mathbf{3 . 2 1}$ \\
Bird movement & 58.76 & 37.50 & 6.42 & $\mathbf{4 9 . 7 3}$ \\
Bird song & 20.62 & 20.00 & 18.00 & $\mathbf{1 9 . 7 9}$ \\
A long line of insects & 3.09 & 7.50 & 14.00 & $\mathbf{6 . 9 5}$ \\
Increase of water in rivers & 10.31 & 12.50 & 8.00 & $\mathbf{1 0 . 1 6}$ \\
Warmer nights in dry weather & 3.09 & 7.50 & 14.00 & $\mathbf{6 . 9 5}$ \\
Other & 0.00 & 15.00 & 0.00 & $\mathbf{3 . 2 1}$ \\
\hline
\end{tabular}


By analogy, Table 6 shows the local techniques used by producers to predict the end of the rainy season and the prolonged dry seasons that lead to droughts. The results indicate that $48.66 \%$ of the sample recognise the end of the rainy season if winged ants make their appearance, while $16.58 \%$ and $13.37 \%$ of the producers indicated that the end of the rainy season is indicated by the appearance of droplets on the grasses early in the morning and when the moon becomes dark, black and cloudy in the morning. Other growers (about 11.23\%) mentioned too cold nights.

Table 6: Prediction of the end of the rainy season

\begin{tabular}{lcccc}
\hline Prediction techniques & BOUGOUNI & KOUTIALA & SIKASSO & TOTAL \\
\hline Light sky colour & 9.28 & 2.50 & 18.00 & $\mathbf{1 0 . 1 6}$ \\
Too many cold nights during the season & 11.34 & 12.50 & 10.00 & $\mathbf{1 1 . 2 3}$ \\
Droplets appear on the herbs & 15.46 & 10.00 & 24.00 & $\mathbf{1 6 . 5 8}$ \\
Dark, black and cloudy moon in the & 11.34 & 12.50 & 18.00 & $\mathbf{1 3 . 3 7}$ \\
morning & 52.58 & 62.50 & 30.00 & $\mathbf{4 8 . 6 6}$ \\
Other &
\end{tabular}

Source: Author's calculations based on field survey data, August-October 2019.

\subsection{Farmers' adaptation to climate change and variability}

A descriptive analysis of the exogenous variables to be used in the output model was carried out in order to determine the variables that affect farmers' choice of adaptation measures to climate variability. Table 7 below summarises the explanatory variables assumed to affect farmers' adaptation strategies to the effects of climate variability experienced in the region over the past 20 years. The results of this analysis have been calculated on the basis of the response of certain market gardeners to the actual adaptation they have adopted.

Table 7: Statistical description of variables in the multinomial logistic regression model

\begin{tabular}{lcc}
\hline Qualitative variables & Absolute frequency & Relative frequency (\%) \\
\hline Gender of producer & - & - \\
Woman & 128 & 66 \\
Man & 66 & 34 \\
Access to climate info & 168 & 86,63 \\
OP membership & 111 & 57 \\
Access to agricultural & 64 & 33 \\
credit & 142 & 73,26 \\
Access to extension & - & - \\
Mode of access to land & 45 & 23.12 \\
Heritage & 4 & 2.15 \\
Purchase & 4 & 2.15 \\
Sharecropping & 138 & 70.97 \\
Donation & 3 & 1.61 \\
Rental & Averages & Standard Deviations \\
\hline Qualitative variables & 37.83 & 11.26 \\
\hline Age of the producer & 10 & 5.11 \\
Household size & 12.66 & 7.97 \\
Experience &
\end{tabular}

Source: Author's calculation based on Field survey, August-October 2019 
The distribution of producers by age shows that the average age of producers is 37.83 . $( \pm 11,26)$ years. The size of households in the study areas is estimated at an average of $10 \%$. $( \pm 5,11)$ people and experience in market gardening is $12.66 \%$. $( \pm 7,97)$ years. The majority of respondents have access to climate information and extension services $(86.63 \%$ and $73.26 \%$ respectively), while few producers have access to agricultural credit (33\%). This is explained by the fact that the vast majority of respondents are women $(66 \%)$, who have less access to land and credit (33\%). The vast majority of plots $(70.97 \%)$ of market gardeners are in VTICS (Garden Champ School) and BPHS. These are fields developed by the World Vegetable Center's $<<$ Horticulture Scaling Project $>>$ and are accessible to market gardeners without any compensation.

\subsubsection{Constraints to adaptation}

During the individual interviews with producers, one question asked whether they have made any adjustments to mitigate the impacts of climate change and what the obstacles to this adjustment are. Lack of information, lack of money, lack of labour, high cost of labour, unavailability of credit, unavailability of inputs, high cost of inputs and low irrigation potential (Figure 1) were mentioned. Most of these constraints are associated with poverty: $85.56 \%$ of the study sample believe that the first obstacle to adapting to the effects of climate change is related to financial constraints (lack of financial resources). Lack of money prevents producers from obtaining the resources and technologies needed to facilitate adaptation to climate change. Research has shown that adjustment to climate change is cumbersome and costly. For example, if farmers do not have enough family labour or financial means to hire employees, they would find it very difficult to adapt. For example, low levels of irrigation are most certainly linked to the inability of producers to use irrigation water. In addition, $67.38 \%$ of producers do not have sufficient knowledge to manage the effects of climate change. In general, farmers in Mali are very poor and do not have the means to invest in irrigation and in research into technologies to adapt to climate change or to maintain their livelihoods in the face of extreme weather conditions, such as floods and drought.

\section{Figure 2: Constraints related to adaptation}

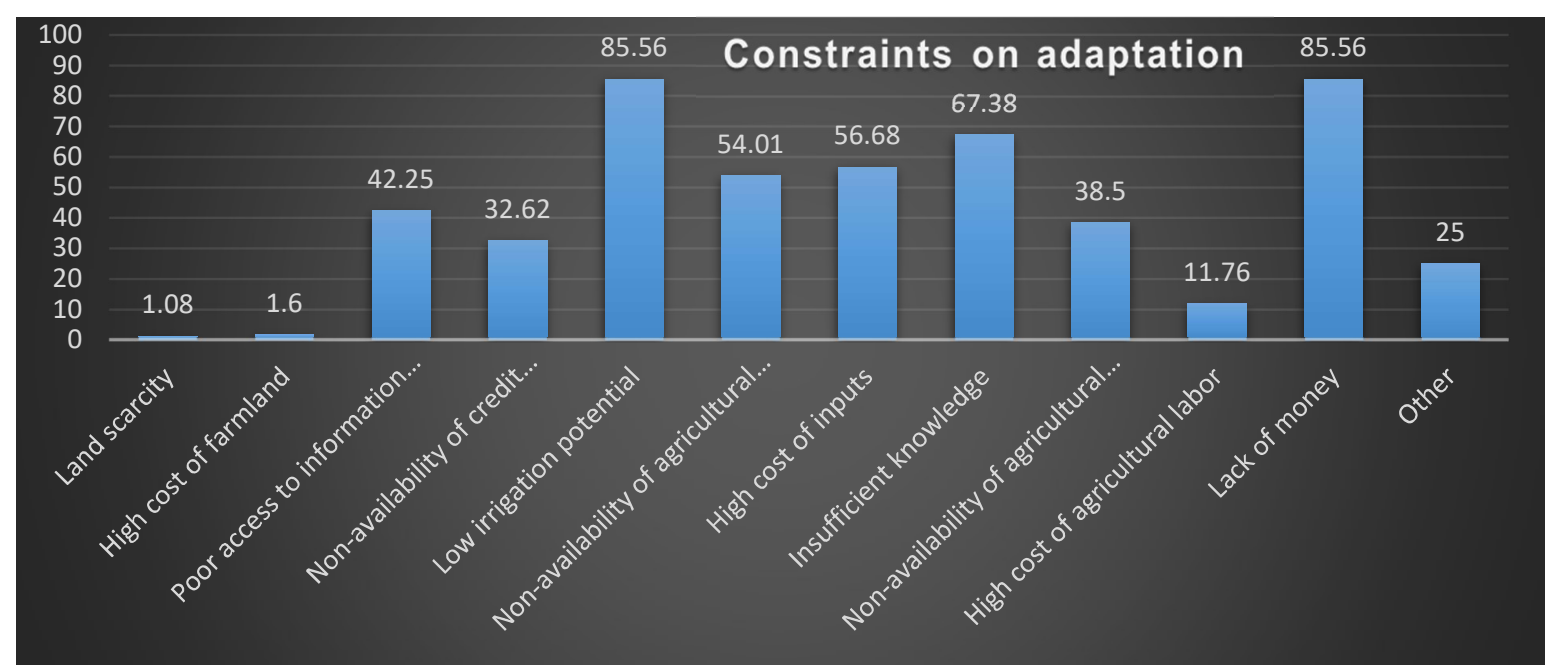

Source: Author's calculation based on Field survey, August-October 2019 


\subsection{Econometric analysis of farmers' perceptions and adaptation measures}

\subsubsection{Econometric models}

Two types of analytical models are adopted for this study. The first model analyses the perceptions and adaptations of market gardeners on climate change, while the second model examines the method chosen by market gardeners to adapt to climate change in the extreme south of Mali.

\subsubsection{Heckman probit results}

Since the study focuses on the 6 major adaptation options (see methodology section), the regression results are also presented in the same specific order for each adaptation option, as shown in Table 8.

\section{Size of household}

The results of the estimation of the adaptation model indicate that: increasing household size influences the increase in irrigation to adapt to changes in temperature and rainfall. Household size is positively significant at $10 \%(\mathrm{p}=0.062)$. This means that the more members of the household, the more likely they are to irrigate their plots. This is justified because almost all the producers interviewed said that they belong to large families and therefore have sufficient labour to carry out all market gardening activities, including possible adjustments or adaptations to climate change, so the choice to increase irrigation can easily be made by a household with a large number of members than a household with few members. Croppenstedt et al (2003) argue that households with more agricultural assets are more likely to adopt agricultural technologies and use them more intensively because they have fewer labour shortages at peak times.

\section{Agricultural experience}

The results of the adaptation model indicate that there is a positive and significant relationship between agricultural experience and irrigation, and agroforestry as adaptation measures $(p=0.011$ and $p=0.060$ respectively), while the relationship between agricultural experience and different crop varieties, and soil and water conservation was found to be negative ( $p=0.096$ and $p=0.009$ respectively). The positive relationship indicates that more experienced farmers are more likely to increase irrigation technology and combine cultivation and tree planting in the same plots to adapt to climate change than less experienced farmers. Since more experienced farmers have experience with farming techniques and information on long-term climate change, they are able to cope with the effects of climate change than less experienced farmers. This result is comparable to the findings of Maddison (2006) and Nhemachena and Hassan (2007) that experience in agriculture increases the likelihood of adopting climate change adaptation measures. While the negative relationship between agricultural experience and SWC (Soil and Water Conservation) may well be the fact that this adaptation option is actually taken by all market gardeners, not just experienced producers. Shiferaw and Holden (1998) found a negative relationship between agricultural experience and the adoption of improved soil conservation practices in their studies.

\section{Access to credit}

Access to credit is positively correlated with the use of drought-resistant crops and soil and water conservation techniques at the $10 \%$ threshold (with $p=0.053$ and $p=0.096$ ) in the model results. Access to credit alleviates financial constraints and allows farmers to invest more in 
diversification activities such as the purchase of fertilizers, improved crop varieties and irrigation facilities. Pattanayak et al (2003) and Yirga (2007) on an analysis of the adoption of agricultural technologies found similar results that there is a positive relationship between the level of adoption and the availability of credit.

\section{Access to agricultural extension}

Results from the adaptation model indicate that the expansion of extension services influences the use of drought-resistant crops to adapt to climate variability. Access to extension is positive and statistically significant at the $1 \%$ threshold $(\mathrm{p}=0.003)$, meaning that extension influences the decision to use drought-resistant crops. This result highlights the role of extension services in mitigating the impacts of temperature and rainfall change. The more a farmer is in contact with extension services, the more useful information he receives on how to manage the effects of climate change. Extension is also positively and significantly correlated with early and late planting at the $5 \%$ threshold.

\section{Mode of access to land}

The relationship between the mode of access to agricultural land and the use of different crop varieties is positively and statistically significant at the $1 \%$ threshold $(\mathrm{p}=0.006)$. The right to land ownership can influence the investment choices of producers and facilitate their adaptation to climate change (Yegbemey et al. 2013). This positive and significant relationship observed between these two variables could be explained by the fact that most market garden produce is grown on developed plots and offered free of charge to market gardeners by the WoldVeg Horticulture Project.

\section{Belonging to a farmers' organisation}

Membership of a farmers' organisation is positively and significantly correlated with soil and water conservation (at the $1 \%$ significance level, $\mathrm{p}=0.003$ ). Farmers' organisations can benefit from technical training from their development partners (No Governmental Organisations (NGOs), agricultural development projects and programmes) to raise awareness on the origins and consequences of climate change on agricultural production and human activity, as well as the measures to be adopted (Yegbemey et al. 2014). The vast majority of the producers interviewed belong to farmers' organisations, associations and can receive upstream and downstream training on modes of resilience to climate change.

\section{The gender of the producer}

The gender variable is positively and significantly correlated with agroforestry adaptation measures (at the $1 \%$ threshold, $\mathrm{p}=0,000$ ). This result reflects the fact that men are more involved in this activity than women and have more access to climate information. Male headed households are more likely than female headed households to obtain information on new technologies and to engage in risky activities (Asfaw and Ademassie, 2004).

\section{Access to climate change information}

In addition, the results of the adaptation model indicate that access to information on climate change provides incentives for producers to adopt strategies to reduce the damage of present and future climate change. The access to information variable is positive and statistically significant (at the 1\% and 5\% threshold) to all adaptation measures in the study. Farmers with access to climate change information are less inclined to take risks. These results confirmed the findings of Yirga (2007) and Nhemachena and Hassan (2007). 


\section{The age of the producer}

There is a positive and significant relationship between the age of the producer and the soil and water conservation technique on the one hand, and on the other hand between age and early and late planting at the $5 \%$ threshold ( $\mathrm{p}=0.036$ and $\mathrm{p}=0.037$ respectively). As the age of the producer is assumed to represent agricultural experience. Thus, older producers are more likely to observe and adapt to climate change compared to younger producers.

The results of the selection model reveal that the relationship between agricultural experience and producers' perceptions of adapting to climate change is negative and statistically significant. This result can be explained by the fact that some of the producers who claimed to perceive changes, unfortunately did not take any adaptation measures to minimize the negative impact of climate change, due to their limited financial capacity.

Moreover, membership of a farmers' organisation is positively and significantly correlated with the perception of the adaptation of soil and water conservation measures (at the statistical threshold of $1 \% ; p=0.003$ ). In addition to the technical training available to producers organised in groups, it also serves as a channel for the transmission and exchange of experiences between farmers.

The results of the selection model indicate that the level of education of the producer influences his or her perception of climate change. This implies that educated producers are more likely to make a decision at planting time (sooner or later), increase irrigation, use drought resistant crops, buy different crop varieties, practice agroforestry and adopt soil and water conservation techniques compared to producers without education. The better educated the producers are, the more skills and knowledge they have about climate change than illiterate producers. According to Igoden, Ohoji and Ekpare (1990); Lin (1991) and Madisson (2006), there is a positive relationship between the level of education of the household head and the adoption of improved technologies. In other words, the more educated farmers are, the more they develop strategies to adapt to climate change. 
Tableau 8: Heckman's probit model results

\begin{tabular}{|c|c|c|c|c|c|c|c|c|c|c|c|c|}
\hline \multirow{3}{*}{ Explanatory variables } & \multicolumn{4}{|c|}{ Increase irrigation } & \multicolumn{4}{|c|}{ Drought-resistant crops } & \multicolumn{4}{|c|}{ Different varieties of crops } \\
\hline & \multicolumn{2}{|c|}{ adaptation model } & \multicolumn{2}{|c|}{ perception model } & \multicolumn{2}{|c|}{ adaptation model } & \multicolumn{2}{|c|}{ perception model } & \multicolumn{2}{|c|}{ adaptation model } & \multicolumn{2}{|c|}{ perception model } \\
\hline & Coef. & P-values & Coef. & P-values & Coef. & P-values & Coef. & P-values & Coef. & P-values & Coef. & \begin{tabular}{|l} 
P- \\
values
\end{tabular} \\
\hline Age of the producer & -0.012 & 0.430 & & & 0.014 & 0.385 & & & -0.001 & 0.873 & & \\
\hline Size of household & $0.011^{*}$ & 0.062 & & & 0.006 & 0.314 & & & -0.003 & 0.460 & & \\
\hline Experience & $0.037^{*}$ & 0.060 & $-0.027^{*}$ & 0.058 & $0.274 * *$ & 0.022 & $0.845^{* * *}$ & 0.003 & $-0.334^{*}$ & 0.063 & $-0.372^{*}$ & 0.096 \\
\hline Gender of producer $(1 / 0)$ & -0.126 & 0.637 & 0.227 & 0.375 & 0.185 & 0.473 & 0.170 & 0.519 & 0.076 & 0.712 & 0.052 & 0.832 \\
\hline Membership OP (1/0) & -0.089 & 0.733 & 0.352 & 0.139 & -0.145 & 0.563 & 0.074 & 0.755 & -0.033 & 0.872 & 0.012 & 0.961 \\
\hline Access to credit (1/0) & -0.060 & 0.815 & & & $0.518^{*}$ & 0.053 & & & 0.233 & 0.235 & & \\
\hline Access to extension $(1 / 0)$ & -0.201 & 0.410 & & & $0.773 * * *$ & 0.003 & & & 0.062 & 0.732 & & \\
\hline Mode of access to land & -0.017 & 0.864 & & & -0.001 & 0.994 & & & $0.227^{* * *}$ & 0.006 & & \\
\hline $\begin{array}{l}\text { Access to climate info } \\
(1 / 0)\end{array}$ & $1.207^{* *}$ & 0.022 & & & $0.612 * *$ & 0.048 & & & $0.847 * * *$ & 0.002 & & \\
\hline Level of education & & & $0.237^{*}$ & 0.059 & & & $0.287 * *$ & 0.039 & & & $0.244 *$ & 0.094 \\
\hline Constant & $-1.648^{*}$ & 0.058 & $1.314^{* * *}$ & 0.000 & $2.053^{* * *}$ & 0.005 & $0.701 * * *$ & 0.008 & $-1.187^{* *}$ & 0.042 & $1.404 * * *$ & 0.000 \\
\hline Observation & 194 & & & & 194 & & & & 194 & & & \\
\hline Censored observation & 29 & & & & 29 & & & & 29 & & & \\
\hline Uncensored observation & 165 & & & & 165 & & & & 165 & & & \\
\hline Wald chi2 (9) & 15.19 & & & & 19.61 & & & & 22.04 & & & \\
\hline Prob>chi2 & 0.0858 & & & & 0.0205 & & & & 0.0087 & & & \\
\hline
\end{tabular}




\begin{tabular}{|c|c|c|c|c|c|c|c|c|c|c|c|c|}
\hline \multirow[b]{3}{*}{ Explanatory variables } & \multicolumn{4}{|c|}{ Agroforestry } & \multicolumn{4}{|c|}{ Soil and water conservation } & \multicolumn{4}{|c|}{ Early and late planting } \\
\hline & \multicolumn{2}{|c|}{ adaptation model } & \multicolumn{2}{|c|}{ perception model } & \multicolumn{2}{|c|}{ adaptation model } & \multicolumn{2}{|c|}{ perception model } & \multicolumn{2}{|c|}{ adaptation model } & \multicolumn{2}{|c|}{ perception mode } \\
\hline & Coef. & P-values & Coef. & P-values & Coef. & P-values & Coef. & P-values & Coef. & P-values & Coef. & $\begin{array}{l}\mathrm{P} \text { - } \\
\text { values }\end{array}$ \\
\hline Age of the producer & 0.006 & 0.622 & & & $0.026^{* *}$ & 0.036 & & & $0.029 * *$ & 0.037 & & \\
\hline Size of household & 0.003 & 0.603 & & & -0.004 & 0.465 & & & 0.003 & 0.562 & & \\
\hline Experience & $0.030 *$ & 0.060 & $0.919 * *$ & 0.023 & $-0.576 * *$ & 0.017 & $-0.042 * * *$ & 0.009 & $-0.214^{* *}$ & 0.041 & $0.205^{* *}$ & 0.024 \\
\hline Gender of producer (1/0) & $0.779 * * *$ & 0.000 & 0.180 & 0.464 & -0.055 & 0.819 & 0.542 & 0.151 & -0.115 & 0.631 & -0.360 & 0.222 \\
\hline Membership OP (1/0) & 0.212 & 0.329 & -0.156 & 0.508 & 0.196 & 0.377 & $0.813^{* * *}$ & 0.003 & -0.189 & 0.436 & 0.185 & 0.515 \\
\hline Access to credit (1/0) & -0.132 & 0.552 & & & $0.348^{*}$ & 0.096 & & & 0.146 & 0.548 & & \\
\hline Access to extension (1/0) & 0.207 & 0.355 & & & 0.183 & 0.363 & & & $0.444^{* *}$ & 0.049 & & \\
\hline Mode of access to land & -0.016 & 0.847 & & & -0.025 & 0.780 & & & 0.143 & 0.116 & & \\
\hline $\begin{array}{l}\text { Access to climate info } \\
(1 / 0)\end{array}$ & $0.935^{*}$ & 0.081 & & & $1.239 * * *$ & 0.000 & & & $0.931 * * *$ & 0.001 & & \\
\hline Level of education & & & $0.233^{*}$ & 0.053 & & & $0.396 *$ & 0.090 & & & $0.509 * *$ & 0.024 \\
\hline Constant & $-2.036^{* * *}$ & 0.001 & $1.199 * * *$ & 0.001 & -0.765 & 0.232 & $1.667 * * *$ & 0.000 & & 0.008 & $0.916 * * *$ & 0.006 \\
\hline Observation & 194 & & & & 194 & & & & 194 & & & \\
\hline Censored observation & 29 & & & & 29 & & & & 29 & & & \\
\hline Uncensored observation & 165 & & & & 165 & & & & 165 & & & \\
\hline Wald chi2 (9) & 25.02 & & & & 33.50 & & & & 50.55 & & & \\
\hline Prob>chi2 & 0.0030 & & & & 0.0001 & & & & 0.0000 & & & \\
\hline
\end{tabular}

${ }^{*} \mathrm{p}<0.10,{ }^{* *} \mathrm{p}<0.05,{ }^{* * *} \mathrm{p}<0.01$ 


\section{CONCLUSION}

This study identified the socio-economic, infrastructural and institutional factors that influence the perception and adaptation of producers to climate change in the extreme south of Mali. Heckman's probit model was used to analyse these variables using data collected from producers in the communes of Koumantou, Sanso and Zantiebougou in the Bougouni cercle, Niéna in the Sikasso cercle and Zankaso in the Koutiala cercle. Using the results of Heckman's probit it was found that market gardeners in the extreme south of Mali perceive climate change and develop various strategies to adapt to it. For these producers, climate change manifests itself in changes in rainfall and temperature patterns, floods, droughts, land degradation and the drying up of rivers. Increased irrigation, use of drought-resistant crops, use of different varieties, agroforestry, soil and water conservation and planting time (sooner or later) are the main adaptation strategies developed as a response to perceived climate change.

Thus, the results indicate that experience in agriculture and the level of education of producers are the two main determinants of the simultaneous perception and adaptation of producers to climate change. Among these variables, agricultural experience is both positively and negatively correlated with perception.

In the light of the above, awareness-raising, information, exchange and sharing of experience relating to extreme climatic conditions could be undertaken to consolidate the different endogenous strategies developed by local producers in the implementation of policies to promote agriculture in general, and vegetable production in particular.

\section{List of abbreviations}

ECOWAS: Economic Community of West African States

IPCC: Intergovernmental Panel on Climate Change

FAO: Food and Agriculture Organisation

MEADD : Ministère de l'Environnement, de l'Assainissement et du Développement Durable

OECD: Organisation for Economic Co-operation and Development

UNDP: United Nations Development Program

WCA: World Vegetable Center

\section{References}

Asfaw, A., and A. Admassie. 2004. The role of education on the adoption of chemical fertilizer under different socioeconomic environments in Ethiopia. Agricultural Economics 30 (3): 215-228.

Bhavnani, R., S. Vordzorgbe, M. Owor, and F. Bousquet. 2008. Status of disaster risk reduction in the sub-Saharan Africa region. The World Bank, Washington, DC. https://www.unisdr.org/files/2229_DRRinSubSaharanAfricaRegion.pdf

CIMMYT Economics Program. 1993. The Adoption of Agricultural Technology: A Guide for Survey Design. Mexico, D.F.: CIMMYT. 
Croppenstedt, A., M. Demeke, and M. M. Meschi. 2003. Technology adoption in the presence of constraints: The case of fertilizer demand in Ethiopia. Review of Development Economics 7 (1): 58 70 .

Deressa et al. 2009. "Determinants of Farmers "Choice of Adaptation Methods to Climate Change in the Nile Basin of Ethiopia." Global Environmental Change. Centre for Environmental Economics and Policy in Africa (CEEPA), University of Pretoria, RSA, Room 2-4, Agric. Annexe, Pretoria 0002, South Africa

Gbetibouo. 2009. "Understanding Farmers "Perceptions and Adaptations to Climate Change and Variability: The Case of the Limpopo Basin, South Africa." Washington, D.C.USA. http://ebrary.ifpri.org/utils/getfile/collection/p15738coll2/id/31770/filename/31771.pdf

IPCC, 2014. Climate Change 2014: Impacts, Adaptation, and Vulnerability. Part B: Regional Aspects. Contribution of Working Group II to the fifth Assessment Report of the Intergovernmental Panel on climate change. Cambridge University Press, Cambridge, UK. Report edited by V. Barros, T.F. Stocker, D. Qin, D.J. Dokken, K.L. Ebi, M.D. Mastrandrea, K.J. Mach, G.-K. Plattner, S.K. Allen, M. Tignor, and P.M. Midgley (eds.)]. Cambridge University Press, Cambridge, UK and New York, NY, USA, 696 pp. https://www.ianas.com/Food/ClimateChange_IPCC_B.pdf

IPCC. 2013. Climate Change 2013: The Basis of the Physical Sciences. Contribution of Working Group I to the Fifth Assessment Report of the Intergovernmental Panel on Climate Change. Stocker TF, Qin D., Plattner G.-K., Tignor M., Allen SK, Boschung J., Nauels A., Xia Y., Bex V., Midgley PM (eds.), Cambridge University Press, Cambridge, United Kingdom and New York, NY, USA, $\quad 1535$ pp. https://www.ipcc.ch/site/assets/uploads/2018/02/WG1AR5_all_final.pdf

Igoden, C., P. Ohoji, and J. Ekpare. 1990. Factors associated with the adoption of recommended practices for maize production in the Lake Basin of Nigeria. Agricultural Administration and Extension 29 (2): $149-156$.

Leeuwis, C. and A. van den Ban (2004). Communication for rural innovation: rethinking agricultural extension. Oxford [etc.], Blackwell Science.

Lin, J. 1991. Education and innovation adoption in agriculture: Evidence from hybrid rice in China. American Journal of Agricultural Economics 73 (3): 713-723.

Maddison, D. 2006. The perception of and adaptation to climate change in Africa. CEEPA. Discussion Paper No.10. Centre for Environmental Economics and Policy in Africa. Pretoria, South Africa: University of Pretoria. https://openknowledge.worldbank.org/bitstream/handle/10986/7507/wps4308.pdf?sequence= $1 \&$ is Allowed $=y$

Ministère de l'Environnement et de Développement Durable (MEDD), 2018. Plan d'investissement pour une économie verte et résilience aux changements climatiques pour le Mali. Rapport Final. https://www.greenclimate.fund/sites/default/files/document/mali-country-programme.pdf

Nhemachena, C., and R. Hassan. 2007. Micro-level analysis offarmers' adaptation to climate change in Southern Africa. IFPRI Discussion Paper No. 00714. International Food Policy Research Institute, Washington, D.C. https://www.researchgate.net/publication/5056602.

Pattanayak, S. K., D. E. Mercer, E. Sills, and Y. Jui-Chen. 2003. Taking stock of agroforestry adoption studies. Agroforestry Systems 57(3): 173-186. 
PNUD, 2014. RENFORCER LES CAPACITÉS D'ADAPTATION ET LA RÉSILIENCE AUX CHANGEMENTS CLIMATIQUES DANS LE SECTEUR DE L'AGRICULTURE AU MALI. https://www.adaptation-undp.org/sites/default/files/resources/ccaf_brochure_mali_fr.pdf

RUSHIGIRA C, (2017). Analyse technico-économique de la production maraîchère à Kamanyola dans la plaine de la Rizizi/RDC : Contraintes et stratégies d'acteurs. Mémoire de Master en développement, Environnement Sociétés, Université de Liège; 129p. https://s3arch.page/results.php?q=Rushigira_67381600_2017.pdf

Sultan B. 2011. L'étude des variations et du changement climatique en Afrique de l'Ouest et ses retombées sociétales. Habilitation à diriger des recherches, Université Pierre et Marie Curie, 137 p.https://pagesperso.locean-ipsl.upmc.fr/bslod/hdr_sultan_manuscrit.pdf

THOMAS A., 2000. Économétrie des variables qualitatives, Dunod, 2000. 22p.http://excerpts.numilog.com/books/9791037626011.pdf

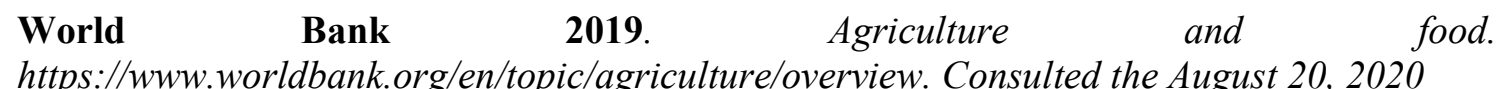

https.//www.worldbank.org/en/topic/agriculture/overview. Consulted the August 20, 2020

Yegbemey RN, Yabi JA, Aïhounton GB, Paraïso A, 2014. Modélisation simultanée de la perception et de l'adaptation au changement climatique : cas des producteurs de maïs du Nord Bénin (Afrique de l'Ouest). Cah Agric 23 : 177-87. doi : 10.1684/agr.2014.0697.

Yegbemey RN, Yabi JA, Tovignan DS, Gantoli G, Kokoye SEH, 2013. Farmers' decisions to adapt to climate change under various property rights: a case study of maize farming in Northern Benin (West Africa). Land Use Policy 34: 168-75. Doi: 10.1016/j.landusepol.2013.03.001

Yirga, C. T. 2007. The dynamics of soil degradation and incentives for optimal management in Central Highlands of Ethiopia. PhD thesis. Department of Agricultural Economics, Extension, and Rural Development. University of Pretoria, South Africa. https://repository.up.ac.za/bitstream/handle/2263/25333/Complete.pdf?sequence $=6$ 


\section{Appendix}

Figure 2: Mapping the southern region of Mali

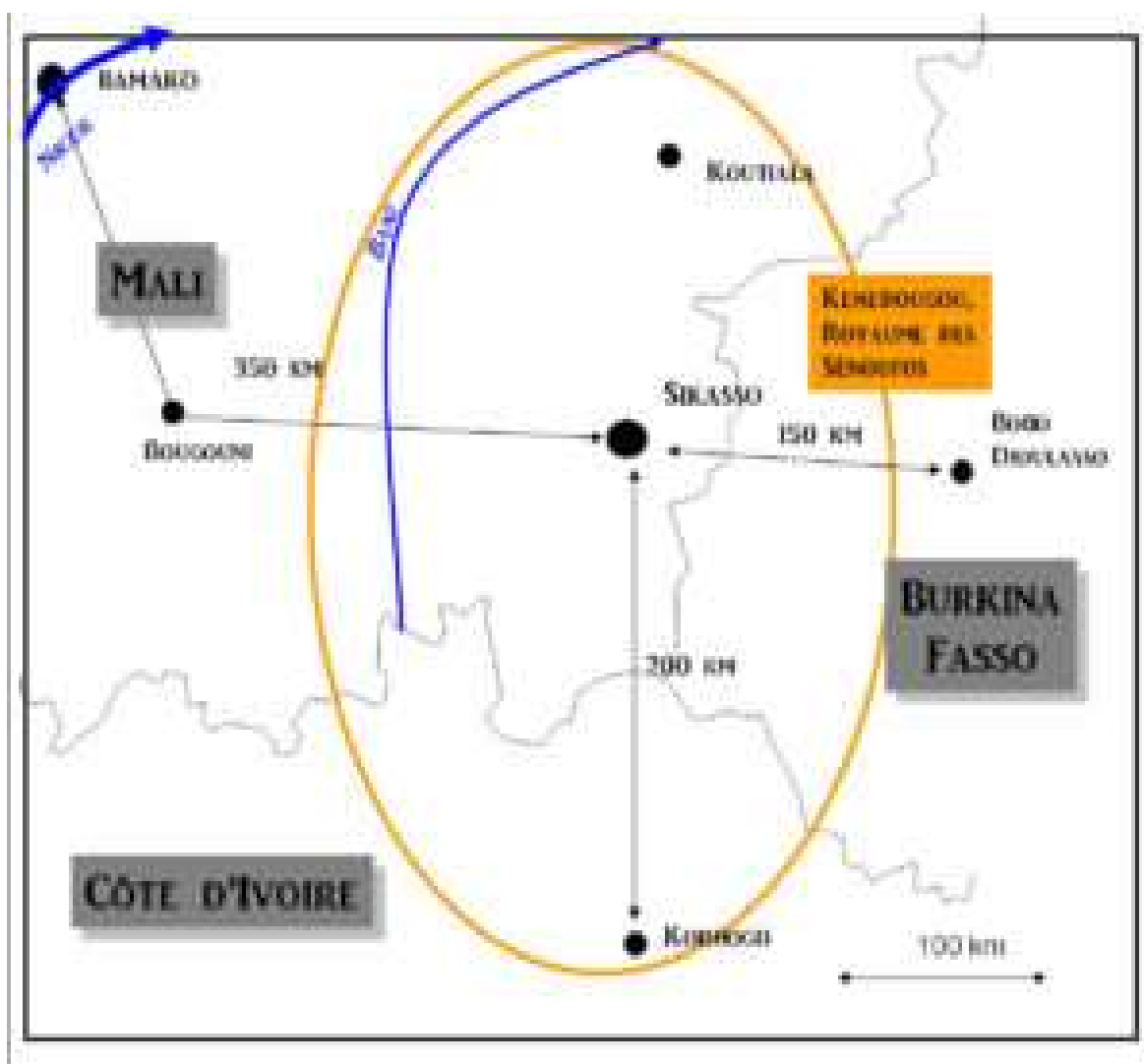

